\title{
Tainted Law? The Italian Penal Code, Fascism and Democracy
}

\author{
Stephen Skinner \\ Senior Lecturer in Law, Exeter University, Cornwall Campus ${ }^{1}$
}

\begin{abstract}
The current Italian Penal Code is the direct descendant of the 1930 Rocco Code. Originally a hybrid of authoritarian and liberal elements, but revised and reinterpreted in the post-war Republic, the Code was nevertheless introduced under the Fascists and has not been definitively reformed or renamed. Given such roots, this article argues that the Code's legitimacy can be questioned by considering the significance of the Fascist past in terms of the Code's symbolic, contextually narrative and memorial dimensions. On this basis the article develops a concept of tainted law in order to ground and direct analysis of law in relation to the anti-democratic past, arguing that critical engagement with the connections between law and the darker episodes of twentieth-century politico-legal history is vital to the construction and conservation of democratic legal systems today.
\end{abstract}

\section{Introduction}

The current Italian Penal Code has a complex status, a fragmented identity and a history marked by political extremes. It is directly descended from and bears the name of the Rocco Penal Code of 1930, which was drafted during the regime of Benito Mussolini under the direction of the Fascist Minister of Justice, Alfredo Rocco, and entered into force on $1^{\text {st }}$ July 1931. At the time of its introduction, the Code bore the Fascist stamp on its structure and numerous key provisions, but in substantive terms was not entirely authoritarian. In the post-war Republic, the Code was not replaced but has

\footnotetext{
1 This article is based on papers presented at the British Legal History Conference (Exeter, July 2009, with the assistance of funding from the Society of Legal Scholars), the European Society for Comparative Legal History Inaugural Conference (Valencia, July 2010) and the 9 ${ }^{\text {th }}$ International Roundtable for the Semiotics of Law (Poznan, September 2010). I thank participants at each event for their valuable observations (especially Dirk Heirbaut, Lorie Charlesworth and Valerio Nitrato Izzo) and am particularly grateful to the following for commenting on various drafts of this article: Catherine Dupré, Richard Ireland, David Fraser, Michael Livingstone, Jenny McEwan and Thomas Watkin. Any errors are my own.
} 
Forthcoming in the International Journal of Law in Context, vol. 7, 2011

been revised in a piecemeal fashion and reinterpreted to bring it into line with the democratic Constitution of 1948. As a result, in terms of its predominant normative content and application, it is not substantively a Fascist code today - and yet the Fascist shadow still lies upon it.

The Italian Penal Code is thus in name and origin, structure and - in places - conceptual foundations, connected with the Fascist past. In a modern European State that considers itself a democracy, where the Fascist past is still a vivid part of socio-political discourse, and where post-Fascists formed until recently part of the governing coalition, this authoritarian legacy is contextually and politically disturbing. Moreover, as many of the European States involved in the development of a new supranational constitutional order have themselves emerged from an authoritarian past, the question of how to assess and interpret historical shadows on current law is of wider importance. In legal and jurisprudential terms though this issue is problematic: if law in its application complies with democratic norms, how can its more abstract, conceptual or associative links with the authoritarian past be shown to matter?

Italian legal commentary predominantly focuses on the law in practice and its compatibility with the Constitution, and ignores these more conceptual questions. Similarly, in the recent human rights case of Giuliani 
Forthcoming in the International Journal of Law in Context, vol. 7, 2011

and Gaggio v Italy ${ }^{2}$ the European Court of Human Rights also focused on Italian criminal law's substantive application in order to sidestep an 'abstract' argument raised by the applicants that, because of its Fascist origin, a key provision of the Penal Code (Article 53 on the legitimate use of arms, discussed in detail below) was incompatible with the right to life under Article 2 of the European Convention on Human Rights (ECHR). ${ }^{3}$ Consequently, from this pragmatic or formalistic perspective, what matters in the relationship between law and the higher democratic norms embodied in the Italian Constitution and ECHR is substance and practice.

Yet, it is argued here, the legitimacy of law and its relationship with democracy needs to be understood more broadly, with a particular focus on contextual significance and historical experience. Taking democracy to mean an aspirational and idealistic model ${ }^{4}$ of political community based on liberty, human rights, the rule of law, and representative and accountable institutions of government, this argument is based on the view that although democracy is a sufficiently flexible concept to allow for a range of manifestations, if it is to avoid becoming a relativistic simulacrum it must be grounded on certain key values. Part of these values, it is argued, can be found through a reflexive,

2 Giuliani and Gaggio v. Italy (App. No. 23458/02), European Court of Human Rights $4^{\text {th }}$ Section Chamber judgment of August 25, 2009 (case commentary in [2009] European Human Rights Law Review, 830-833) and Grand Chamber judgment of March 24, 2011. For the background to and details of the original incident and legal analysis see Skinner, 2003.

${ }^{3}$ The applicants also challenged Italy's 1931 public order law. For further analysis of this issue in relation to the Chamber judgment see Skinner, 2010.

${ }^{4}$ Birch, 2007, pp.111-112. 
Forthcoming in the International Journal of Law in Context, vol. 7, 2011

critical relationship with democracy's foundational objectives, especially the rejection of the legal rules, principles and legacies of an antecedent political order that was anti-democratic, or authoritarian. This argument is constructed in three stages.

First, the article situates the Italian Penal Code in national and comparative perspective, before outlining the extent to which authoritarian characteristics were identifiable in its original formulation and have been removed through post-war reforms. The argument presented in this part is that prima facie most of the Code's authoritarian aspects have been corrected, but that certain Fascist characteristics are still identifiable.

The article then moves in its second stage to consider the Code's significance beyond its substantive aspects. The article diverges from the wellknown debate about the legitimacy and legality of (post-) authoritarian law as set out by Herbert Hart, Lon Fuller and David Dyzenhaus, in order to distinguish law's nature and content from its broader socio-political significance. Here the article draws on Jürgen Habermas's analysis of the tensions between the facticity and validity of law by arguing that there are key tensions between law's (internal) functionality and its (external) symbolic and narrative significance; and between a pragmatic amnesty in law's application and the importance of history and memory. Central to both of these, the article argues, is a socio-political awareness of historical experience which undermines the Code's perceived legitimacy in its contextual setting. 
Forthcoming in the International Journal of Law in Context, vol. 7, 2011

In its third stage, the article argues that this socio-political critique of the Penal Code's legitimacy provides the basis for formulating a new conceptual model encapsulating the tensions in law's legitimacy in relation to its history. Drawing on Andreas Kalyvas's political theory of the extraordinary, which he proposes in order to re-orient critical analysis of democracy towards a more multi-faceted comprehension of its origins, and on the work of Robert Cover, Austin Sarat and Thomas Kearns on law and (foundational) violence, the article sets out a concept of 'tainted law.' It argues that this concept can provide a methodological basis for focusing attention on, and articulating the ways in which law, its legitimacy and democratic values are inter-connected through a foundational relationship based on rejection of the anti-democratic past, and that as such this concept can be used to ground and guide critical analysis of law in democracy. Such issues and the need for an ongoing critical engagement with the authoritarian past, the article concludes, resonate beyond the borders of Italy and relate to broader international discussions about the construction and conservation of democracy today.

\section{Fascism and the Rocco Code}

The Rocco Code of 1930 was introduced under the Fascist regime that lasted from 1922 to 1943 . This regime began with a will to control Italian society through repressive measures (Canali, 2009) and developed into a brutal 
system, allied with the Nazis. Authoritarian in style, that is putting the State and its interests above individuals and their liberties, Mussolini's Fascist regime strove for a corporatist, absolute dominance of all aspects of Italian life in such a way that it is generally considered to be the first totalitarian order. ${ }^{5}$ The regime actively pursued aggressive foreign policies and was domestically violently repressive of press and workers' freedoms, dissent and political opposition (Knox, 2002; Gentile, 2002; Paxton, 2004; Bosworth, 2006). Indeed, according to R. J. B. Bosworth in his leading study of Fascist Italy, the regime was a "vicious and retrograde tyranny" whose actions at home and abroad "must bear responsibility for the premature death of a million people" and which "holds a prominent place in the black book of human misdeeds in the twentieth century" (Bosworth, 2006, pp. 1-4).

The 1930 Penal Code replaced the preceding Zanardelli Code of 1889, which came into force in 1890 and was unified Italy's first penal code (Vassalli, 1974, p.1037; Pulitanò, 2007, p.85). The Rocco Penal Code was not though the only law code formulated by the Fascist regime, which also introduced a new Code of Penal Procedure in 1930 and a new Civil Code and

\footnotetext{
5 'Totalitarian' in the sense of the Fascist State meant that individuals, commerce and industry, social life and private organisations were all deemed to be part of one totality serving the interests of the State. The extent to which the Italian Fascist State is best described as totalitarian or authoritarian has however been re-appraised in recent scholarship: Gentile, 2002, pp.139-140; and the meaning of 'fascism' in the Italian context is insightfully examined and challenged by Paxton, 2004. For Hannah Arendt, the principal totalitarian orders were Nazi Germany and Stalinist Russia, with Mussolini's dictatorship appearing only peripherally: Arendt, 1951/1985. Detailed engagement with these issues falls beyond the scope of this paper.
} 
Forthcoming in the International Journal of Law in Context, vol. 7, 2011

Code of Civil Procedure in 1942. Whereas recent commentators have considered that the two civil codes were not so influenced by Fascist ideology, the Code of Penal Procedure was profoundly permeated by authoritarian ideology and significantly reduced the rights of suspects (Delitala, 1960; Watkin, 1997, p.42). ${ }^{6}$ Of the four, only the Penal Procedure Code has been replaced by a new code, introduced in 1989,7 with the other codes being retained but adapted and amended.

It is also important to recall at the outset that the Italian Penal Code is not the only law in Europe with a difficult, even undemocratic origin. Just as other Italian codes also stem from the Fascist era, elsewhere in Europe examples can be found of penal codes which, after the fall of a dictatorship, were retained and revised for transitional periods, but in contrast with Italy were later replaced, such as in Germany, Spain and some post-communist States (Bolle, 1999, p.393; Riera, 1996). The current Portuguese Penal Code began as a draft under the Salazar regime, but was reworked before entering

6 The American commentator, Morris Ploscowe, writing in 1945 was damning in his assessment of Fascist criminal procedure: "Fascist Italy made profound changes in the Italian Code of Criminal Procedure and in Italian methods of administering criminal justice. The fundamental purpose of these changes was to strengthen the dictatorship which Fascism exercised upon the Italian people. The machinery and the processes of criminal justice were intended to make possible the expeditious elimination of those who were, or who were presumed to be, enemies of the regime. Unfortunately, the Fascist reforms of criminal justice were not limited to political cases in which the Fascist regime was directly interested or involved. [...] In the repression of political as well as of ordinary crimes Fascism endowed police, prosecuting and administrative officials with such wide powers that the individual was completely at their mercy. Police officials were placed above the law." (1945, p.240).

7 The new Penal Procedure Code sought to shift Italian procedure towards a more AngloAmerican adversarial model and to increase its efficiency, but not without problems: see Grande, 2002. 
Forthcoming in the International Journal of Law in Context, vol. 7, 2011

into force under the democratic order (Bolle, 1999, p.393; de Figueiredo Dias, 1995). Similarly, older examples of leading European penal codes, subsequently held up as models, did not stem from democratic orders, such as the Bismarckian and Napoleonic codes (Bolle, 1999, p.394). Indeed in Italy, although the 1889 Zanardelli Code was much praised at the time of its introduction as a model of liberal and criminologically classical legislative drafting and went on to be influential on penal codes abroad (including Turkey and Australia), it was not itself unproblematic nor the product of a democratic legal order in today's sense (Pulitanò, 2007, p.85; Vassalli, 1960, p.269). Even laws in common law systems, which are deemed to have longer democratic traditions, are not without politically problematic origins: nineteenth- and early twentieth-century British statutes were passed by a parliament that was not democratic in a twenty-first century sense; key aspects of Anglo-American common law have stemmed from judicial decisions rooted in deeply political and ideological world views, as the critical legal history scholars have highlighted (Gordon, 1984; Kelman, 1987, pp.213241); and some commentators have shown how certain twentieth-century Anglo-American legal practices were not conceptually or substantively different from those in contemporaneous authoritarian States (Lustgarten, 2003; Fraser, 2005; Ewing and Gearty, 2000). ${ }^{8}$

\footnotetext{
8 Wise also makes similar comparative observations in passing with regard to Swiss, Swedish and U.S. criminal law: Wise, 1978, pp.xxxiii and xxxv.
} 
Forthcoming in the International Journal of Law in Context, vol. 7, 2011

The Italian Penal Code is thus not an isolated case of a law with problematic origins, but it is nevertheless a prominent example of a current criminal code with an overt and ongoing link to the Fascist past. Yet critical engagement with the Code has to identify and situate its Fascist dimensions in the complex landscape of more or less democratic and authoritarian legal norms across a range of political systems over time. ${ }^{9}$ Also, although on the one hand the Code was introduced under the Fascists and may be associated with that regime in simple terms of its origin, on the other hand the substantive connections between the Rocco Code and Fascism, together with the question of what makes them politically problematic, is less simple. While a full comparative analysis of the Rocco Code's provisions in relation to preceding Italian law, contemporary law in other countries, and later law is an essential part of this analysis, it must for present purposes fall beyond the scope of this article. ${ }^{10}$ Instead, this article will limit itself to an overview of the Code's genesis, some key examples of its original Fascist characteristics, and an outline of post-war reforms and the Code's authoritarian residue in order to provide the foundations for the paper's principal theoretical argument.

\footnotetext{
${ }^{9}$ See especially on this point Fraser, 2005. Focusing on Nazi law, Fraser argues that critical engagement with authoritarian law has to be undertaken in comparative perspective and requires engagement with both substantive law and its deeper conceptual substructure: pp.25-26.

10 The author is currently developing, through a series of conference papers and articles, a larger research project on these issues including Fascist ideology, criminal law and the Rocco Code's reception in contemporary academic commentary in Italy and abroad, in order to explore these questions of distinction, difference and continuity.
} 
Forthcoming in the International Journal of Law in Context, vol. 7, 2011

At the time of the Code's introduction, it seems that Minister Rocco's intention was to lay the foundations for a new era of criminal law that would support the Fascist regime and move away from previous liberal principles. He is quoted as declaring in 1927, when outlining his plans for the new code, that:

[The Zanardelli Code] failed to take into account the penal protection of the State, except when its external protection was menaced... The dogma of individual liberty, a veritable fetish, adopted in the most exaggerated extremes, legitimated every activity of the citizen, even those contrary to the most vital interests of the State. The principles which inspire the present proposal in this domain are in complete opposition to those which inspired the code of 1890, just as the Fascist conception of the State is opposed to the democratic-liberal conception of the State. ${ }^{11}$

Yet despite Rocco's claims, the extent to which the original Rocco Code was distinctively Fascist or authoritarian, or in line with the preceding Zanardelli Code, or otherwise innovative, is a matter of considerable debate. ${ }^{12}$ The Rocco Code in some ways represented major progress from its predecessor, in its improved precision and internal coherence (Vassalli, 1960, p. 270 and 1974, pp.1048-1049; Wise, 1978, p. xlv), and was welcomed by some as a great step forward (e.g. Battaglini, 1934). When assessing its ideological content, some commentators emphasise that the Code's Fascist influences

\footnotetext{
${ }_{11}$ Alfredo Rocco, Discorso sul Codice Penale, Rome, 30 $0^{\text {th }}$ November 1927, quoted in Steiner, 1936, p.1277.

${ }^{12}$ In general terms, Paxton emphasises the lack of clarity in the range of influences that could loosely be called Italian Fascist ideology and the significant difference between what was declared and what was done: Paxton, 2004, pp. 5 and 10.
} 
Forthcoming in the International Journal of Law in Context, vol. 7, 2011

were mainly confined to a limited number of specific crimes in its Special Part so that it can not really be said to have been a distinctively Fascist code overall (Delogu, 1945; Bettiol and Mantovani, 1986). Others concede that the Code was distinctively authoritarian (thus demonstrating a central attribute of Fascism) in key respects, even though these were not ideologically systematic or peculiar to Italy at the time and the most authoritarian elements of penal law were contained in the special laws that existed alongside the Code (for example Cattaneo, 1981, pp.108-109; Marconi, 1981; Nuvolone, 1981, pp.39 and 45). More generally, despite its debateable ideological coherence and character, the Rocco Code was introduced under Mussolini as part of the regime's efforts to develop a new legal order, which involved the interaction of legislative and institutional elements. ${ }^{13}$

The Code's more clearly identifiable ideological orientation included a new understanding of the law-citizen-State relationship, which focused on the primacy of the State and sought to reformulate the previous tenets of enlightened and classical criminal law resulting from the eighteenth century (Cattaneo, 1981). Fascist understanding of criminal law shifted from the idea of a State-citizen contract under which the power to punish was conceded to the collectivity within limits, to a conceptual model in which the power to

\footnotetext{
${ }^{13}$ For an important recent study of the Fascist impact on the administration of criminal justice and the adaptation of institutional structures to serve ideological ends, see Klinkhammer, 2010. For further commentary on Fascist policing and the courts see Ploscowe, 1945 and Wise, 1978, pp. xxxiii-xxxiv.
} 
Forthcoming in the International Journal of Law in Context, vol. 7, 2011

punish derived from and existed solely in order to protect and uphold the State, and needed no other theoretical justification (Manzini, 1981, p.91). In this light, although much is made by some commentators of the fact that the Rocco Code retained the principle of legality at its heart, confirming in its first article that there could be no punishment without law and thus appearing to adhere to a fundamental liberal value, in fact the Fascist order meant that that principle and the very idea of law changed from their eighteenth-century sense of a guarantee of liberties and a restriction on the State's power to punish, to an authoritarian conception in which law was to be exalted as the expression of State power over its subjects (Piasenza, 1979, p. 272; Pulitanò, 2007, pp.88-89).

Furthermore, the Code's style and structure were also distinctive as compared to the previous Italian Penal Code, and are said to be evidence of the Fascist influence. The Code was drafted in a particular, so-called 'technical-legal' (tecnico-giuridico) style, which was intended to develop a new type of penal code focusing on the primacy of law and punishment over the universalist or anthropological concerns of previous criminological theory, both classical and positivist (Vassalli, 1960, p. 274; Musio, 2005, chapter 1). Although not in itself authoritarian, this style was the product of Fascist efforts to develop a new style of criminal law, with the aim being to achieve a legal purity that would allow for criminal law to be enforced in the interests of the State without being tied to a particular conception of criminality. The 
Forthcoming in the International Journal of Law in Context, vol. 7, 2011

result was a code that nodded to the need for the classical concept of moral fault, but which ignored it in several offences and, as considered below, in its provision for preventative measures based on a determination of dangerousness (real or political) without the need for prior fault (Vassalli, 1974, pp.1044-1046).

With regard to its structure, the Code was set out in a way that represented the Fascist regime's political priorities. Whereas postenlightenment criminal law generally placed crimes against life and physical integrity first, the Rocco Code structured its specific offences, contained in Book II of the Code, in an ideologically motivated hierarchy (Mantovani, 2007, p.xlviii). This began with crimes against the State, followed by crimes against the public and legal administration, religious belief, public order, economy and industry, morality, racial health, the family, before coming at last to crimes against the person and property. Again, although this ordering might not be uniquely Fascist in its inherent hierarchy of values (Marconi, 1981), it nevertheless reflects the regime's focus on the State and general priorities.

The Code was also distinctively authoritarian in many of its specific provisions. As emphasised in Wise's analytical overview, the Rocco Code was "harsh, vindictive [and] atavistically brutal" due to its general increase in the levels of punishment, including basic penalties and through its use of aggravating factors to increase sentences, in addition to its provision for "security measures" that could be used to impose preventative detention 
Forthcoming in the International Journal of Law in Context, vol. 7, 2011

(Wise, 1978, p.xxxv; Vassalli, 1974, pp.1044-1046). In terms of offences the Rocco Code was characterised by its introduction of, for example, crimes protecting the State, repressing dissent and press freedom, protecting the family and race (including the criminalisation of abortion), and prohibiting strike action in order to uphold the Fascist corporate view of economic activity (Vassalli, 1974, pp.1065-1069; Wise, 1978, pp.xxxi-xli; Pulitanò, 2007, pp.85-105). ${ }^{14}$ Consequently, although the Rocco Code is considered not to have been as totalitarian or harsh as contemporary Nazi criminal law and cannot be categorically labeled, it was distinctively authoritarian in key dimensions and reflected significant aspects of Fascist priorities (Wise, 1978, p.xxxii; Mantovani, 2007, pp.xlvii-lii).

With the fall of Fascism, the end of the Second World War and the birth of the democratic Republic, Italy took steps to address the least tolerable elements of the Rocco Code but did not entirely replace it. An emergency decree of 1944 led to a first, limited wave of partial reforms, which were followed over the years by further amendments and abolitions (Mantovani, 2007, pp.lii-liii). As a result, aspects of the Code's General and Special Parts still revealed direct connections with the original Rocco Code long after the war and some still do today. These connections and associations include both substantive elements and other continuities in terminology and classification

\footnotetext{
14 Ferrari also provides a useful outline of key Fascist elements of the Code as part of his analysis of the Code's political uses in the 1970s: see Ferrari, 1981, pp.25-27.
} 
from law introduced by the Fascist regime. Although the full details of the original and residual extent of Fascist influences on the substance of the Code would require lengthy exposition ${ }^{15}$, five examples are briefly considered here in order to show ways in which the Code's Fascist dimensions were addressed, both completely and partially.

The first example is the place of the death penalty in the Penal Code and how it has acted as a 'barometer' of Italian criminal law's passage from a liberal, to a Fascist, to a democratic order. Abolished by the liberal Zanardelli Code, it was reinstated for the most serious crimes under Articles 17 and 21 of the Rocco Code (del Giudice, 2007, pp.88 and 91), such as leading an armed revolt against the State under the original terms of Article $242,{ }^{16}$ or aggravated homicide (such as homicide to conceal another crime, parricide, or homicide with an element of sexual violence) under the original terms of Article 576. ${ }^{17}$ Whilst recourse to the death penalty was not unusual in Europe at the time, its reinclusion in the Rocco Code is held up as an example of the latter's severity in contrast to the previous, post-Beccarian, more humane penal provisions in Italy and a distinctively intimidatory, Fascist element (Crespi et al, 2008, pp.59-60). The death penalty was then abolished again by the 1944 emergency decree, confirmed by Article 27 of the democratic Constitution of 1948, and replaced in the Penal Code with life imprisonment, although

\footnotetext{
15 The Italian literature on this is, unsurprisingly, extensive.

${ }_{16}$ Del Giudice, 2007, pp.342-343.

17 Ibid, pp.725-726.
} 
Forthcoming in the International Journal of Law in Context, vol. 7, 2011

retained for certain military crimes under Article 241 of the Military Penal

Code until it was repealed for reasons of incompatibility with the ECHR in 1994 (Crespi et al, 2008, p.84). In this respect therefore a particularly authoritarian aspect of the Code was swiftly removed.

The second example involves Chapter II, Title II of Book II, which covers crimes by individuals against the public administration. These include, among other offences, Article 336, violence or threats against a public official; Article 337, resisting a public official; and Article 338, violence or threats against a political, administrative or judicial body. Recent Italian commentary points out that under the Zanardelli Code, these offences were not applicable if the public official had brought about the resistance or threats by arbitrarily exceeding his or her powers (del Giudice, 2007, p.459). The Fascist authors of the Rocco Code, however, removed this limitation in order to allow for the enforcement of unconditional obedience to the State. As part of the 1944 emergency revisions after the fall of Fascism, the Code was amended to reintroduce the restriction on these offences included in the Zanardelli Code, ${ }^{18}$

\footnotetext{
${ }^{18}$ A dissenting voice on this specific point can be found in Delogu (1945), who presented a counter-argument to the allegation that the Code favoured State authority over the citizen, based on Article 61 of the Penal Code, which lists aggravating factors that can lead to an increased penalty. Although para. 10 of Article 61 included (and still includes) the commission of a crime against a public official as an aggravating factor, Delogu pointed out that para. 9 covered (and does still) the abuse of power by a public official as an aggravating factor. Moreover, Delogu argued that the effect of excluding the arbitrary exercise of power limitation from Chapter II, Title II, Book II of the Rocco Code was not so significant as the citizen could still rely on Article 52 on legitimate defence.
} 
Forthcoming in the International Journal of Law in Context, vol. 7, 2011

again illustrating how an authoritarian dimension of criminal law was rectified.

A third example is from the Rocco Code's specific provisions aimed at enforcing a particular set of moral values through the protection of the family, values which current commentary identifies closely with the Fascist political agenda. By way of illustration, the original Code contained specific offences aimed at preserving the sanctity of marriage, such as Articles 559 and 560, which punished with imprisonment offences of adultery and the keeping of a mistress. The former was declared invalid by the Constitutional Court in 1968-69 and the latter in 1969 (del Giudice, 2007, p.706). More seriously, Title $\mathrm{X}$ of Book II of the Code contained provisions on crimes against "the integrity and health of the stirpe [a word indicating family, or race]", which regulated maternity and strictly prohibited abortion. Although a leading voice in postwar commentary on the Code questioned the significance of Title $\mathrm{X}$, arguing that it was concerned solely with preserving the birth rate and health of the population, rather than being a set of racial laws along the lines of the Nazi criminal code, its aim to enforce a particular set of family and moral values was clearly in line with Fascist ideology, even if as Delogu points out some of its provisions derived from the pre-Fascist code (Delogu, 1945, p.186). Although racial laws were passed by the Fascists later in the 1930s they were not part of the Code, a fact relied on by Delogu to argue that the Rocco Code was not an explicitly racist law and that its provisions on the stirpe were 
Forthcoming in the International Journal of Law in Context, vol. 7, 2011

therefore not politically problematic (Delogu, 1945, p.186). Nevertheless, subsequent commentators agree that this section bore an unmistakably Fascist stamp and it was eventually entirely repealed in 1978 (del Giudice, 2007, p.702). Again, this example shows how the Code was revised to remove an authoritarian dimension, but in this instance the revision took over thirty years to be completed.

The fourth example is drawn from Title I, Book II of the Penal Code on Crimes Against the Personality of the State. This section of the Code originally contained crimes "aimed at repressing acts of political and ideological dissent deemed capable of damaging the Italian State"19 (del Giudice, 2007, p.337; Crespi et al, 2008, pp.633-638). After a range of offences of revolt and insurrection, treason, espionage, and incitement to disaffection, come the particular offences under Articles 269 and 270. Article 269, which criminalised the spreading of rumours abroad aimed at undermining the prestige and reputation of the State, was a clear example of the Fascist drafter's aim of upholding the authority and glory of the State. Article 270, which punished activities related to 'subversive associations', is considered to be a paradigm example of the Fascist regime's declared intention to crack down on political parties and other organisations opposed to it, particularly (given its original wording which included reference to the dictatorship of a social class) the communist party (del Giudice, 2007, pp.371-372; Crespi et al, 2008, pp.691-

\footnotetext{
${ }^{19}$ Author's translation.
} 
Forthcoming in the International Journal of Law in Context, vol. 7, 2011

697). According to recent commentary, the offences in this part of the Code were not removed after the war, but were largely deemed to have been impliedly repealed by the Constitution and were not applied, until that is they became useful in the fight against terrorism in the 1970s (del Giudice, 2007, pp.371-372; Ferrari, 1981). However, this part of the Code was finally revised in 2006, apparently due to a belated recognition of the conflict the provisions represented in relation to the Constitution and prevailing liberal democratic values, with changes including the repeal of Article 269 and revision of Article 270 to remove the explicit focus on communist activity and reorient it towards violent threats to the State (del Giudice, 2007, p.338). This example thus illustrates an even longer process of reform and, more importantly, indicates how originally authoritarian provisions became useful to the democratic State in a period of emergency. In this regard, there were clear substantive continuities in the Code and its application long after 1943.

The fifth and final example is Article 53 on the legitimate use of arms, (a key provision challenged by the applicants in the Giuliani case, mentioned in the introduction, above). Unlike the last four examples, this provision has not been amended in an explicit reform even though it is clearly authoritarian in origin and character. This provision of the Rocco Code specifically exempts from punishment a public official who uses a weapon or other means of physical coercion, if it is necessary to do so to repel an act of violence or overcome some other form of resistance, in order to carry out an official duty. 
Forthcoming in the International Journal of Law in Context, vol. 7, 2011

Under the Zanardelli Code, a similar provision was included under the articles relating to the fulfilment of a duty, legitimate defence and necessity, providing public officials an extra margin of action but only within the terms of those specific forms of justificatory defence. Under the Rocco Code, the drafters made the provision distinct, in order to emphasise the significance of State authority and power (Crespi et al, 2008, p.205). Even so, despite the broad terms of Article 53, it seemed prima facie at the time of the Code's introduction that the criminal courts would still have to determine whether any force used by State agents was in fact legitimate under the Code. In reality, however, Article 16 of the Criminal Procedure Code meant that police or military personnel could not be prosecuted for any use of arms without the authorization of the Minister of Justice, a political officer appointed directly by Mussolini. Consequently, under the Fascists the legal system was stacked in favour of State agents, with the justificatory provision of Article 53 representing more of an inherent presumption than a form of defence that would need to be relied on (Ploscowe, 1945, p.246).

As it stands today, Article 53 is a controversial throw-back to the authoritarian era. Most commentators point to the reservation in the first line of Article 53, which states that it applies if the preceding two articles on legitimate defence or fulfilment of a duty do not, in order to show that its scope is limited; other commentators maintain that it is autonomous in its application and constitutes an additional justificatory provision for State 
agents (Crespi et al, 2008, p.205; del Giudice, 2007, pp.141-142). More serious is the fact that Article 53 still does not contain a requirement of proportionality in relation to the force used. However, given its authoritarian origin and apparent condonement of disproportionate force, the article has been interpreted restrictively in post-war doctrine and practice, in light of the Constitution and the ECHR, with a requirement of proportionality read into it (Crespi et al, 2008, p.207; del Giudice, 2007, p.142; Skinner, 2003, pp.243-244). The article itself and its bare terms nevertheless constitute a surviving element of authoritarian law, albeit interpreted through the filter of constitutional and human rights provisions.

These examples illustrate post-war Italy's strategies for dealing with the Rocco Code in the absence of a general replacement: some repeals and explicit amendments over a long period, and some requalification and interpretation of provisions to ensure compatibility with the democratic norms set out in the Constitution and ECHR. ${ }^{20}$ This is not to say that reform projects have been lacking, for numerous proposals have been put forward over the decades since the end of the war, but have not been implemented. ${ }^{21}$ This has been due to a range of factors, including lack of political will, flaws

\footnotetext{
${ }^{20}$ Further examples of conflicts between the Penal Code and the Constitution could include the principle of individual criminal responsibility and the re-educative purpose of punishment, the lawfulness of strike action, and the recourse to preventative detention: for further details see Mantovani, 2007, p.LIII and Palazzo and Papa, 2000, pp.196-198. Key specific studies of the relationship between the Code and the Constitution include Dolcini and Marinucci, 1996, and Siniscalco, 1976.

${ }^{21}$ The Italian literature commenting on these projects is extensive, but convenient summaries may be found in Palazzo and Papa, 2000 and Pulitanò, 2007.
} 
Forthcoming in the International Journal of Law in Context, vol. 7, 2011

in the proposals, the weakness of coalition governments and, significantly, the particular strains and crises that Italy has faced in the form of political terrorism, such as the 'years of lead' period of terrorist activity in the 1970s, and the ongoing struggle with organised crime (Palazzo and Papa, 2000, pp.198-201; Musio, 2005, chapters 2 and 3; Pulitanò, 2007, pp.102-103). In these difficult circumstances it has sometimes been convenient for the authorities to have recourse to some of the stringent, authoritiarian, provisions that were still available in the Rocco Code (as indicated above), supporting the view that a certain 'Fascistic' mentality survived (Ferrari, 1981; Marconi, 1981, p.136; Dondi, 1999, p.155). There has at the same time been a tendency in academic commentary to focus on the cleansing effects of amendments to the Code and liberal-democratic interpretation, to reinterpret the presence of the principle of legality in the Rocco Code and its technical-legal style in order to argue that the Code is not so authoritarian or problematic, and to downplay the Code's origins in the name of expediency (see especially Piasenza, 1979 and Neppi Modona, 2007; also Pulitanò, 2007, pp.90-105; Wise, 1978, p.xxxii;). Consequently, although the predominant view in academic commentary is that the Rocco Code is no longer the same as, or even comparable to, the original code (for example Pulitanò, 2007, p. 103), it is nevertheless a Code that has Fascist roots, is at odds with the needs of a modern pluralistic 
democracy, ${ }^{22}$ and retains disturbing echoes of the Fascist past in its structure and aspects of its residual terms.

The survival of a key area of law with Fascist connections reflects the widely recognised fact that Italian democratization after the Second World War did not lead to a clean break from the Mussolini years (Bull and Newell, 2005, pp.4-9; Duggan, 1995, pp.1-24). ${ }^{23}$ Indeed, the conflictual driving forces in post-war Italy of anti-fascism and anti-communism, on top of the long lasting divisions along these ideological lines flowing from the internal conflict at the war's end (Ginsborg, 1990, pp.72-120)24, mean that issues of Fascist connections (although not the only conflictual forces at play in modern Italy nor evident in homogeneous forms) are still relevant and a source of sociopolitical tension today (Bosworth, 2006, chapter 18; Foot, 2009, chapters 3, 5 and 7). Although it has been noted that for some Italians such matters are merely a detail in the country's complex political "topography" (Jones, 2008, pp.4-7), much as Fascist buildings are part of many Italian cityscapes, ${ }^{25}$ they are nevertheless still deeply-rooted sources of conflict. ${ }^{26}$

Such issues are particularly important in contemporary Italy given the recent composition of its governing coalition, which included the post-Fascist

\footnotetext{
22 See for example Romano (1987, p.7) and the conclusion in Musio (2005).

${ }^{23}$ Bosworth and Dogliani refer to "the decidedly gentle and incomplete purge of servants and sympathisers of the dictatorship in the immediate aftermath of 1945", 1999, p.3. Major studies include Battini (2007) and Pavone (1974).

${ }^{24}$ For a more journalistic, narrative account see Montanelli and Cervi, 2007.

25 See for example Foot, 2009, p.69.

${ }^{26}$ For a specific illustration see Foot, 2009, chapter 8 and compare Jones, 2003, pp.27-60.
} 
Forthcoming in the International Journal of Law in Context, vol. 7, 2011

Alleanza Nazionale party of Gianfranco Fini, who became deputy prime minister under the leadership of Silvio Berlusconi, and the treatment of the Fascist past by key coalition members (Dondi, 1999, pp. 154-156; Bosworth, 2006, pp.557-560). This included efforts to downplay the negative associations of Fascism and to recast it as a respectable political movement acting in Italy's best interests by comparison with the misdeeds of other States and political groups, especially Stalinist Russia and communist partisans in Italy (Pivato, 2007, pp.87-101; Stoltzfus and Bosworth, 2009, pp.566-585). ${ }^{27}$ This sort of comparative argumentation, highly controversial in Italy, echoes the very relativising process that Habermas found so disturbing in Germany twenty years before and which triggered an explosive outcry about relations with the Nazi past (Habermas, 1988). Moreover, the fact that Fascism remains a bitterly divisive and dangerous political force in Italy has also been in the spotlight of public attention following key moments of social conflict in recent years. ${ }^{28}$

\footnotetext{
${ }^{27} \mathrm{~A}$ recurrent theme in post-war Italian public and political life has been the fluctuation in Fascistic, anti-Fascist, and anti-anti-Fascist readings and reinterpretations of history: Bosworth and Dogliani, 1999, pp.6-7.

${ }^{28}$ During and after the G8 protests in Genoa in 2001, the events that led to the Giuliani case referred to above, references to Fascism and evidence of its influence were a key part of media, NGO and popular discourse: many newspaper reports focused on the presence of neo-fascist agitators among the protesters, neo-fascist elements in the police forces involved in acts of violence against demonstrators sleeping in the Diaz School dormitory and detained at the Bolzaneto barracks (including forcing detainees to sing Fascist songs), recourse to 'Fascist' laws to prosecute members of protest groups, and the criticism that police behaviour was in appearance and essence 'Fascist'. Print and internet media coverage of these issues is vast, but informative references include: Fusani (2002), Shabi and Hooper (2005), Hooper (2008), and Davies (2008). Other key documentation includes: Statewatch (2001), Amnesty International (2001), Genoa Social Forum (2002), Maccanico (2008).
} 
Forthcoming in the International Journal of Law in Context, vol. 7, 2011

Drawing all of the above points together, the suggestion here is that the connections between the Penal Code and the Fascist past are identifiable and significant at two levels. One such level, outlined here but requiring further engagement, is the Code's substantively authoritarian content, both historically and in terms of its effects and continuities today, in the Code and the modes of thinking it supports. At another level are the contextual and associative socio-political resonances of the Code's connections with the Fascist past, through its name, structure, origin and lineage. Focusing on this second level of significance, the argument here is that the connection with the Fascist past is meaningful and problematic due not only to (not insignificant) reasons of political antipathy, but also to reasons that are identifiable in terms of legal theory.

\section{The Italian Penal Code, the Fascist Past and Legal Theory}

Perhaps the best known analysis of the legitimacy or otherwise of authoritarian law is contained in the Herbert Hart and Lon Fuller debate, and its subsequent reprisal by scholars such as David Dyzenhaus (Hart, 1958; Fuller, 1958; Dyzenhaus, 1996, 1997 and 1999). The Hart-Fuller debate arose in the late 1950s specifically with regard to questions about the validity of Nazi criminal law, and Dyzenhaus's work began with similar questions about the law under the South African apartheid regime, before focusing on law in the Weimar Republic and other systems under stress. In essence and as it is well 
Forthcoming in the International Journal of Law in Context, vol. 7, 2011

known, whereas Hart argued for a distinction between law as it is and ideas of what law ought to be, in order to uphold a positivist interpretation of law which separated its procedural validity and applicability from moral judgements about its content and substantive legitimacy, Fuller (and subsequently Dyzenhaus) argued that questions of legality cannot be separated from questions of legitimacy, and therefore that the interpretation and application of law have to be understood in relation to a broader moral framework if law is to be of value in society.

The argument presented here, however, is not about the nature of law in terms of its content and compatibility with acceptable morality, substantively or procedurally, nor is it about whether law that could be deemed authoritarian can bear the name of law, or satisfy the rule of law. Rather, the argument here is that there is more to the relationship between law, its legitimacy and democracy than the former's procedural and substantive attributes as assessed and applied according to the latter's tenets. The article argues instead that law's significance and perceived legitimacy, and thus its relationship with democracy, reside not only in how it is made, what it contains and what it is made to do, but also in what it projects, what it 


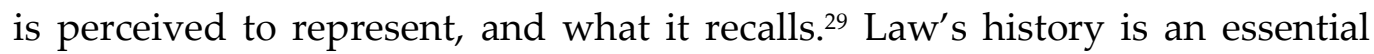
element of all of these.

In its historical and current contextuality, the argument is influenced by the work of Habermas, due to his analysis of the relationship between history and democracy, highlighted above, and because of his analysis of the tension between the facticity of law and its validity (that is between law's institutional administration and enforcement, and its contextually-bound and -bounded legitimacy) in a way that tries to place that analysis within an integrative conception of social life (Habermas, 1996, pp.9, 20, 30, 80-81). ${ }^{30}$ The argument is also influenced by Habermas's vision of communitarian democracy, to the extent that democracy's potential and aspirational evolution into a revitalised form of socio-political organisation must be anchored in law, and in shared perceptions of that law's legitimacy (Habermas, 1996, pp.104 and 458). ${ }^{31}$ In this light (although the aim is not to present a strict application of Habermasian theory to the issues under discussion) the two branches of the argument are presented as tensions, in order to express the idea that there may be incompatibilities, conflicts and divergences between the operation of a legal order and wider perceptions of its meanings and impact. The first tension considered here is between an

\footnotetext{
${ }^{29}$ Compare the analysis of criminal law's legitimacy in terms of an internal (doctrinal) and external (socio-political and social perception-oriented) duality in Fiandaca and Musco, 1994, p.25.

30 The 'Translator's Introduction' to Habermas (1996) by William Rehg is also useful: see e.g. p.xii. For further illuminating discussion see Dyzenhaus (1996).

${ }^{31}$ For further useful discussion of Habermas in this regard see Carlsson, 2002, pp.89-90.
} 
Forthcoming in the International Journal of Law in Context, vol. 7, 2011

internal analysis of law's functionality, and law's external symbolic power and narrative locus (section 3.1); and the second is between pragmatic amnesty in the application of law, and the broader social role of memory in legal and political life (section 3.2).

\subsection{Law's Symbolic Power and Narrative Locus}

The first tension addressed here is between the effect of law as the result of an institutional process, that is an internally analytical understanding of law, and its significance in a broader cultural framework as a symbolic force and as part of a narrative. Both involve values related to democracy and its principles, but both raise and apply such values in different ways.

A leading explanation of an internally-focused, institutionally-oriented understanding of law is found in the work of Neil MacCormick (2007). For MacCormick, law is an institutional normative order in that it involves the systematic application by institutions of expressly articulated norms (or values), drawn from the wider pool of values upheld by a particular society. Such institutions operate within the bounds of constitutional principles, such as the separation of powers, and the key factor in understanding them and their significance is, according to MacCormick, their functionality (2007, pp.49 and 305). One manifestation of this is the way in which a court will approach cases in its jurisdiction, that is the extent to which it will be more or less positivist, activist, or political in its decisions, which will depend on the 
Forthcoming in the International Journal of Law in Context, vol. 7, 2011

express or implied limits on its activity set by the overall system in which it operates in relation to other institutions of democracy, such as legislative and executive bodies. The extent to which the institutional normative order coincides with the wider normative order depends on these operational parameters.

It is suggested here that law may well be understandable as an institutional normative order, but this focuses on the functionality of law and institutions only in terms of application, and is therefore limited. Law also has a communicative and normatively representative function in its form, the way it is perceived and its relational connections beyond its institutional applications. Law is thus arguably interrelated with the normative order that produces it, and that it reflects, in ways that are more abstract, less to do with functionality and more to do with character, or associative identity: this is the symbolic dimension of law, which resonates above and beyond such functional differences and affects perceptions of its significance and legitimacy. ${ }^{32}$

32 Law's symbolic dimension has recently been discussed by Jiří Přibáň (2007). Přibáň is primarily concerned with obstacles to cultural unity that arise from the use of constitutional law, specifically in relation to the construction of European identity, by looking at frictions in legal, political and social modes of communication as identified on the basis of sociological systems theory. According to Přibán, law is both a functionally specific system and a bearer of "expressive and evaluative symbolism", which reflects the way law "internalizes" the identity of the society in which it operates, as well as reflecting back that identity and a sense of that society's cultural, moral and political values and expectations, which he likens to the idea of the spirit of law (Přibáň (2009)). My argument is different from Přibáń's because I am not following a systems theory approach and am concerned with law's symbolic dimension in terms of social perceptions of its significance, rather than in the two-way social identity 
Forthcoming in the International Journal of Law in Context, vol. 7, 2011

One way of understanding this is simply the nexus between law and politics: although law and legal reasoning may be relatively self-contained and may generally be separate from politics in democratic orders, law and legal institutions are an essential part of such orders' broader political context (Waldron, 2004, p.354). As such the law (and decisions under it) carries with it a weight of political significance and associations. These include the political principles and ideological bases such law embodies, association with the government that introduced it, and the political significance of the moment, or process, leading to a particular law's formulation. Such political connections exist in people's political understanding and perceptions of law and as such are identifiable and qualifiable, to the extent that they can be, as matters of opinion and approval: softer points of reference than the internal logical tenets of analytical legal theory, but arguably central to socio-legal analysis.

Another aspect of the symbolic power of law depends on the specific type of law in question and its purpose: in this regard it is particularly important that the object of discussion here is a penal code, because of both its codified and penal nature. Codes of law are based on a distinct way of understanding the role of law and the importance of its means of expression. A law code is a special foundational, unificatory, clarificatory, declaratory and

internalization and reflection process set out by Přibáň; however, I share Přibáň's connection between law's power and collective memory: see section 3.2 below. 
Forthcoming in the International Journal of Law in Context, vol. 7, 2011

definitive statement of law, based on a philosophical position regarding its communication and comprehensibility to citizens, a practical concern with how it should most efficiently be formulated as an instrument of governance and, significantly, a political concern with the power that comes from legal control. As such, a law code represents these philosophical, practical and political bases and objectives as much as it constitutes a substantive set of rules in a specific area. As a leading commentator on civil law systems, John Henry Merryman pointed out, the function of a code is to replace the old and found a new order, springing from the government or ruler of the time and generally bearing the name of the codifier, if not of the ruler himself, as representative of that government and what it stood for, or sought to do (Merryman, 1985, pp.26-29). Consequently, the name of a code, and the fact it is a code, bear great symbolic significance.

The fact that the code under discussion here is penal is also important. Continental criminal codes are called penal codes as the focus is on their establishment of the rules circumscribing the State's power to impose penalties, that is to punish. In other words, a penal code focuses on the State's coercive and punitive power over its citizens and subjects: it is the body of rules pertaining to the monopoly of legitimate violence. The importance of this dimension was not lost on contemporary commentators on the Rocco Code: for example, Battaglini (1934, p.278) observed that: 
Forthcoming in the International Journal of Law in Context, vol. 7, 2011

The Italian Penal Code of October 19, 1930 [...] assumes a significance of first rank among all the legislative results of the Fascist Regime. It deals with one of the greatest attributes of sovereignty, that is to say, the power to punish.

Furthermore, penal law sets out the boundaries of individual liberties, prohibiting forms of conduct and setting limits on others. A penal code is thus at the heart of the State-individual-rule of law relationship. Its terms and application demonstrate the nature of that relationship but the code itself, at the symbolic level, is also arguably a potent aspect of how that relationship is perceived. In this sense, a code in force today that retains a Fascist 'flavour' must be assessed in terms of its content and effects, but in symbolic terms the residual mark of its origins means that the Code signifies values and experiences at odds with what that relationship is expected to be today. Although the Code was a Fascist legal instrument for a fraction of the time it has been in force in the post-war constitutional Republic, the Code's origin nevertheless lives on at the symbolic level irrespective of its post-war adaptation and, in essence, sends the 'wrong message' about State-individual power relations.

A third aspect of the symbolic power of law, specifically a penal code, draws the above issues together through its focus on law's position in the complex web of human society. An influential analysis that encapsulates this idea is to be found in Robert Cover's work on the relationship between nomos and narrative (1983). According to Cover, law has to be understood not only 
in its own terms, but as achieving a meaning and effect through its place in the broader social and cultural narratives that societies develop about what it is, what it does, and what it means (1983, pp.95-96):

We inhabit a nomos - a normative universe. [...] In this normative world, law and narrative are inseparably related. Every prescription is insistent in its demand to be located in discourse - to be supplied with history and destiny, beginning and end, explanation and purpose. And every narrative is insistent in its demand for its prescriptive point, its moral. History and literature cannot escape their location in a normative universe, nor can prescription, even when embodied in a legal text, escape its origin and its end in experience, in the narratives that are the trajectories plotted upon material reality by our imaginations.

For Cover, the meaning of law is to be found in the application of legal rules, but not only there. Law's meaning is also to be found in its narrative framework, in the thicker (as explored by Geertz, 1973) socio-cultural significance it acquires (Cover, 1983, p.5). In this sense, the symbolic power of law indicates a deeper and wider set of associations beyond the political. Again, such matters are more sociological and anthropological than (analytical) jurisprudential, yet in Cover's analysis are no less significant for jurisprudential understanding. The narratives in which law exists, and which shape and are shaped by attitudes to it, both reflect and construct law's wider significance beyond function and effect. In such a narrative understanding of law in society, law's associations and implications are as significant as its terms and outcomes. 
Forthcoming in the International Journal of Law in Context, vol. 7, 2011

As indicated above, Fascism and its manifestations, related historical awareness and memory, as well as current socio-political resonance all form parts of a complex narrative web in Italy..$^{33}$ Italian law and legal institutions also, applying Cover's model, sit in a narrative web (or better still a web of narratives) that is closely interwoven with the narratives of political life and memory. Arguably the Italian Penal Code has absorbed a fragmented sense of identity, which reflects and symbolises Italy's piecemeal post-war legal transition. Although it reflects the transition to a liberal democratic order through its reform and interpretation in practice, the Code remains a potent symbol of the dark past that has not been excised, or exorcised.

In short, the symbolic value of law is not only to be found in what the law does, but also in what it represents, which has both current and historical dimensions. Law, especially codified law, derives from specific political actors and socio-political moments. As such it retains a connection with its origin, a particular narrative or symbolic value. This is arguably especially true if the origin is unusual, extreme or, as in the case of the Italian Penal Code, an antidemocratic and repressive regime. The symbolic and narrative dimensions of (a particular) law may incorporate dimensions of its substance and application, but also range more widely over aspects of the life of law that go beyond its technical elements and effects. Consequently, even if in practice

\footnotetext{
33 This complexity is emphasised by historians - there are many histories, memories and narratives of Fascism in Italy: see for example, Bosworth and Dogliani, 1999, p.6.
} 
Forthcoming in the International Journal of Law in Context, vol. 7, 2011

democratic norms and processes are respected, there can be a significant conceptual difference and tension between that law as an institutional normative order and the broader normative and narrative orders in which it is located.

\subsection{Law and History, Memory and Amnesty}

The second tension that is suggested here to exist between the functionality of law and its legitimacy as considered in a broader contextual perspective involves the relationship between law, history and memory, and as such can be seen as a more specific aspect of the idea of law's narrative locus outlined above. More precisely, this tension involves considering the significance of the Penal Code's connection with the Fascist past in terms of the well-known debates about law and collective memory in the construction of democracy, in counterpoint to a pragmatic view that it is more important to focus on law's applied usefulness, thereby and in order to do so, forgetting its past. Building on the previous section of this paper, the argument here is that the Penal Code's historical connections still resonate in collective memory and that this means they cannot - and should not - be ignored.

The connections between law, history and memory have been vital components in work on the authoritarian past in Europe, its relationship with legal thinking today, and law's role in transitional justice, that is justice after oppression, genocide or other atrocities. Some of this work has been explicitly 
Forthcoming in the International Journal of Law in Context, vol. 7, 2011

influenced by Habermas's argument that there is a fundamental connection between the building of democratic political community and a critical awareness of the constitutive force of history in forming the conditions of possibility for present thought and action (Habermas, 1988, pp.43-44; Joerges and Singh Ghaleigh, 2003, p.ix; Torpey, 2003, pp.1-34). Other key work on law's authoritarian past has avoided an instrumental or (perceived risk of a) deterministic approach to historiography, but has nevertheless sought to examine past authoritarian law to support current critical reflection and ethical awareness of that law's lingering shadows (Stolleis, 1998, pp.25-39). Work on transitional justice has focused on the connections between law, memory and justice, based on the view that law is inherently connected with memory and is a vital part of processes of coming to terms with a difficult, traumatic or oppressive past, both as part of the problem and as an instrument of justice (Minow, 1998; Teitel, 2000; Barahona de Brito et al, 2001; Christodoulidis and Veitch, 2001).

Much of the work in this area focuses on reconciliation and the transition to democratic government, emphasising the fundamental point that dealing with the non-democratic past is essential to the introduction and development of democracy. A key question here though is of course what is meant by transition, and how long such a period can be said to last. On the one hand, a narrow reading of transition would hold that it relates essentially to the initial period of nascent democracy, in which case a country that has 
Forthcoming in the International Journal of Law in Context, vol. 7, 2011

moved beyond the initial phase of democratization (such as contemporary Italy, over 60 years after the adoption of its post-war democratic constitution), can be considered to be established and no longer in transition. On the other hand, a longer-term reading of transition that focuses on the development of democracy after authoritarianism could suggest that it continues as long as there are "legacies of violence" to be addressed (Barahona de Brito et al, 2001, p.1), with an emphasis on democracy-building as a continuing process (Teitel, 2000, p.5). The crucial point though is that there is a connection between the legacies of the violent past, dealing with them, and the construction of a democratic system. ${ }^{34}$ In this sense, facing the past is an enduringly important issue and grounds the relationship between political memory and justice with regard to law's problematic legacies, for the past remains with us (Barahona de Brito et al, 2001, p.37):

[...] the past continues to live in the present, to a greater or lesser extent. Terms emerge to describe the effects of past events on national cultures. Hence the 'Vichy Syndrome,' the 'Vietnam complex' in the United States, and the various German terms for working through the past and the guilt of the past, all of which indicate that the past is a disease of sorts, a burden on the present. Thus, even after it has ceased to become a part of the active political agenda, the past can continue to be a source of

\footnotetext{
${ }^{34}$ It is important to note here that the idea of 'dealing with' the past is of course complex and has long exercised leading scholars: see for example Adorno (1986, pp.114-129). As a recent paper in this journal emphasised, transitional justice is better understood more broadly than short-term criminal accountability and law reform, and raises wider political, institutional and constitutional issues: Bell, Cambell and Ní Aoláin (2007, p.83).
} 
Forthcoming in the International Journal of Law in Context, vol. 7, 2011

conflict in the judicial arena and of latent or overt deep-seated social animosities. $^{35}$

The importance of remembering and the role of law is a recurrent theme in this area of scholarship. Some significant work has drawn on the concept identified by Maurice Halbwachs as collective memory, that is a way of understanding the interdependence of individual and group memory, and the way such memories interact in, and through, a society's systems of ideas and symbols (Coser, 1992). Such work argues on that basis that law is used to construct and reconstruct current relations with the past in the name of justice, feeding into and interacting with collective memory (Teitel, 2000, pp.69-71; Czarnota, 2001, pp.115-128; Přibáň, 2007, pp.59-68). These arguments understand law as an adaptable constitutive force in the formation, reflection and conservation of collective memory, serving justice through memory, but also serving power through the control of memory (Czarnota, 2001; Herrman, 2008, pp.167-168). Where law serves to address the past and deal with historic injustice in order to direct society towards reconciliation, or closure, it has been said to represent a "foundational moment", which can be interpreted as "a break from the past, a basis for the transformation of state and society, a turning point for it, a reconfiguration of

\footnotetext{
${ }^{35}$ By way of further explanation, West Germany dealt with its Nazi past through a process of Vergangenheitsbewältigung, or overcoming the past, whereas dealing with the Communist past following the unification with East Germany was approached through a process of Aufarbeitung, or working through the past (Müller, 2001, pp.248-274).
} 
Forthcoming in the International Journal of Law in Context, vol. 7, 2011

its normative framework" (Balint, 2001, pp.132-133). In these analyses, law is a vehicle for change, crystalising and reconfiguring the past, memory and thus the social narrative.

Yet such work makes these connections on the basis of change and newness, where law intervenes in response to (recent) past events. The Italian Penal Code, in contrast, is more complicated. Whereas the will to change the Code was evident in the emergency reform measures of 1944 and subsequent amendments, and a crucial 'transformative' moment extrinsic to the Code came with the Constitution of 1948, the Code itself still represents a continuity with the past in name and lineage. Nevertheless, it is argued here that these same factors of collective memory, law as memorial and as a foundational moment are still significant, but in a negative and fragmentary sense. Arguably, even though the Code today has been extensively amended, its name and identifying date still position its foundational moment in the Fascist past, albeit with a series of subsequent, micro-foundational moments along its incremental path towards democratisation. As a result, this fragmentary identity, with symbolic and narrative connections with the darker past, mean that the Code is ambiguous and contestable. Rather than marking a clear turning point or break with the past, it fosters discordant strands of collective memory. ${ }^{36}$ In this light, it arguably plays in theoretical terms a disruptive,

\footnotetext{
${ }^{36}$ As Teitel argues, the idea of collective memory in the transitional context is not singular or static, but contingent and interwoven with other narratives (2000, p.70).
} 
Forthcoming in the International Journal of Law in Context, vol. 7, 2011

rather than a transitional role in the interaction between law and democracy.

The post-war reforms have removed most substantive traces of Fascism from penal law but have, arguably, merely poured cleaner water into a dirty bottle, or at least a bottle with a dirty label (compare Bolle, 1999, p.395). ${ }^{37}$

However, where the problematic, historic 'evil' is not so recent nor part of the active political agenda, in the sense that its immediate effects and implications are no longer issues of daily importance facing the current government then, even though it is still present and significant in broader social and political discourse, its relevance when assessing law related to that history arguably comes into conflict with the issues of practical necessity and amnesty, or pragmatic disregard. The first of these, practical necessity, indicates an approach to using available law and making it work. With the passage of time it is arguable that if in practice the law is working and meets democratic standards in its application (like the Italian Penal Code), then it is not inherently problematic. This, then, leads to the second possible issue of amnesty, or pragmatic disregard. If contemporary doctrine and practice mean that the Code is deemed to be sufficiently democratic in substantive terms (according to the Constitution and ECHR), combined with the fact that the rawness of the urgent period of post-war transition is six decades in the past,

\footnotetext{
${ }^{37}$ Compare Vassalli's concluding comment, 1974, p.1069: Vassalli declares that he has a "sense of the great gulf which necessarily divides a partial reform from the creation of an entirely new code. An old code, however much it is touched up, always gives the impression of responding to the needs of a different society from the one it is called to serve."
} 
then the importance of political memory could be countered by an argument for overlooking the historical, titular and symbolic associations between the Code and the Fascist past as immaterial and as an unecessary shackle to past conflict. Given that integrated reform or replacement of the Code are not forthcoming, such pragmatic disregard could be seen as the only option.

Yet such arguments would, it is suggested here, dangerously ignore the narrative and symbolic dimensions of law explored in the previous section. Amnesty has been an important tool of transitional criminal justice in the name of peace and reconciliation, but it is suggested here that where the criminal law itself is at stake, its historical connection with a problematic and divisive past should not simply be overlooked, or forgotten. ${ }^{38}$ Although memory can be a burden and a sore, forgetting can annihilate victims and compound the original wrong (Minow, 1998, pp.118-119).

In the absence of a suitable comprehensive reform project in Italy, and government will to see it through, there has been little choice but to 'make do' with the Rocco Code in its current manifestation. As shown, however, the relationship between law and democracy is more than a matter of functional

\footnotetext{
${ }^{38}$ It could conceivably also be possible (for a Devil's advocate) to suggest that erasing the trace of Fascism embodied in the Rocco Code could itself be seen as an act of forgetting, a removal of the nominal reminder of the sort of penal law in opposition to which post war reforms and doctrine have been introduced and developed: the very symbolic connection that can cause narrative conflict could at the same time be a memorial to what must not recur. In certain respects the current Rocco Code appears to embody this sort of explicit 'differance', or juxtapositional reflexivity, and can be seen to contain its own contestable 'other', but such internal tensions are more problematic and detrimental to the Code's cogency and democratic appropriateness than they are usefully memorial. Consequently, the argument here focuses on the opposition between necessity-driven pragmatic disregard and the need for change.
} 
Forthcoming in the International Journal of Law in Context, vol. 7, 2011

frameworks and pragmatic attitudes, and the wider significance of the Rocco Code arguably undermines its legitimacy and democratic acceptability in ways that are additional to substantive discussions about the inadequacy of its reflection of current social norms and expectations. Moreover, this analysis also highlights the tension between the Code and democratic values that could not be addressed in the Giuliani case mentioned at the beginning of this paper. The ECHR, as the cornerstone of the Council of Europe and a crucial part of building democratic normative orders in Europe, represents and is grounded on principles born from (among other influences) a rejection of authoritarian regimes. ${ }^{39}$ The Italian Penal Code's connections with Fascism therefore mean that it appears to collide conceptually and ideologically with those fundamental democratic values, but in ways that are beyond the jurisdictional powers of the European Court of Human Rights to consider. Consequently, as Italian doctrine (for the most part) and the Strasbourg Court only consider the functional interpretation and application of the Code, the broader significance and implications of the relationship between law and democracy must be addressed elsewhere.

\section{Tainted Law: Facing the Violent Past and Democracy}

The above critique of the Italian Penal Code, which has underlined the importance of law's history, together with this very process of discursive

\footnotetext{
${ }^{39}$ See also Skinner, 2010.
} 
Forthcoming in the International Journal of Law in Context, vol. 7, 2011

critical engagement, serve to support the formulation of a new conceptual model called 'tainted law.' This model is intended to ground and orientate critical discussion of law and democracy where they are affected by shadows of the anti-democratic past. This last stage of the argument is based on the intellectual position that critical engagement with the law-democracy relationship at the conceptual level is both an academic responsibility and a vital part of democracy's socio-political discursive framework, which is essential to its survival. With that broader view in mind, this model is intended to be applicable to the Italian Penal Code and more generally.

The conceptual model of tainted law is developed here by drawing on two theoretical sources. The first of these is Kalyvas's work on the politics of the extraordinary in democracy, which focuses on the origins of democratic orders. Kalyvas has recently argued in support of theoretical engagement with the origins of democratic orders, in order to bring "the politics of beginnings and foundings to the center of the study of democracy" (2008, pp.4 and 295). Casting points of democratic origin in terms of a concept of the extraordinary (based on an "eclectic" reading of Weber, Schmitt and Arendt), Kalyvas has sought to find a way of engaging with the processes of forming democratic polities and related law (although his principal focus is political), in order to address the question of legitimacy and to refocus discussion on foundational "normative ideals" (2008, p.8). As part of this, he has eschewed a narrow jurisprudential approach that would omit "the realm of the symbolic 
Forthcoming in the International Journal of Law in Context, vol. 7, 2011

[including] the transformation of shared meanings, the radical reorientation of collective and individual values, and the construction of new political identities" (Kalyvas, 2008, p.5). This approach, it is suggested here, can be used to support the argument that engaging with the extraordinary origins of democracy requires engagement with the extraordinary origins of law, and that those origins are of ongoing importance in evaluating the relationship between law and democracy, precisely because of such wider symbolic and shared meanings.

The second theoretical source for tainted law is the work of Cover, Sarat and Kearns on the relationships between law and violence, particularly with regard to law's origins when they can be said to constitute a form of foundational violence. In this respect it is suggested here that an authoritarian order that is rejected but thereby represents the transformative point of reference in a subsequent democratization process can be understood in these terms as a form of foundational violence (Cover, 1986, pp.1606-1607; Sarat and Kearns, 1995, pp.3-4). The term violence is used as a signifier of forms of (contested) force, which in relation to the Fascist regime mean that the idea of foundational violence is used in a more concrete and identifiable sense ${ }^{40}$ than rhetorical (compare Cover, 1986) or mythical/mystical (compare Benjamin, 1921/1996 and Derrida, 1990). The significance of this appellation is, though, less in the labelling of the originating regime and more in the effect that such

\footnotetext{
${ }^{40}$ Compare the opening paragraph of part 2, above and the references therein.
} 
Forthcoming in the International Journal of Law in Context, vol. 7, 2011

labelling has: as violence is a negative term, with its connotations of hurt, force and domination, the importance of identifying a foundational violence is that resulting law can be said to be marked by it or, in other words, to be tainted (Skinner, 2009, pp.140 and 145). In this light, the word taint has been chosen because it indicates a stain or blemish, a trace of some bad or undesirable quality, discredit, dishonour or disgrace, and - perhaps most significantly - a contaminating or corrupting influence. ${ }^{41}$ The suggestion is that law deriving from, or connected with, a violent authoritarian regime such as Fascism is tainted, both because of the effect of such foundational violence on it, and because of its contaminating effect (actual or potential) on the politico-legal structure in which it exists. ${ }^{42}$

Historical, foundational violence in law can thus be read as providing a reference point for evaluating law's legitimacy at later stages of democratic development and for providing parameters for law's construction of the future. The anti-democratic order that is rejected is, by way of that rejection, a foundational indicator of what the new democracy must not be, must not become, and must also not forget. Historical violence can thus be a positive constitutive force in democracy. Yet where such a rejection is incomplete and

${ }^{41}$ Oxford English Dictionary Online, $2^{\text {nd }}$ ed. 1989, entries for 'taint' as noun and verb (consulted on $1^{\text {st }}$ October 2010).

${ }^{42}$ In this sense it is not unlike the critical legal historians' aim to identify and examine disruptions in the field of legal doctrine through explanatory critique, in order to improve understanding and foster discussion of ideological conflicts concealed in law (Gordon, 1984). However, it is distinct given that it is intended to engage with law in a post-authoritarian historical and political context rather than the specifically Anglo-American, economicrelations-oriented thrust of critical legal studies. 
Forthcoming in the International Journal of Law in Context, vol. 7, 2011

legal residues remain, taint by the undemocratic past that could disrupt, or threaten, the legitimacy of law, its relationship with democracy, and thereby the democratic credentials of the current legal order and its institutions, is a taint that demands attention. In that sense foundational violence is negatively constitutive, representing a past shadow from which subsequent law must be kept free. In this regard, the conceptual structure of tainted law is put forward as a way of encapsulating the history-law-democracy dynamic and to articulate its politically disturbing dimensions. It provides a way of orientating analysis, both in terms of objects and a methodology for engaging with them.

First, with regard to its objects, tainted law is concerned with law that appears to have been produced, or absorbed and 'sanitised', by a democratic order but which is connected, explicitly or implicitly, with the anti-democratic past. Such a connection, or connections, may be significant in substantive terms as well as at more socio-politically qualitative levels. As the above study of the Italian Penal Code has shown, the substantive basis for critical study is essential but the law's wider symbolic and narrative resonances are significant above and beyond law's functional dimension.

Tainted law may also take various forms, discretely or in combination. For example, the taint may involve a substantive connection between law today and the law of the problematic past, in terms of surviving legal provisions or a continuity in law's conceptual substrata (compare Fraser, 2005 
Forthcoming in the International Journal of Law in Context, vol. 7, 2011

and Lustgarten, 2003). The law may be tainted through another form of direct connection with that past, due for example to its descent from it, or due to an explicit association with it, such as a procedural or institutional link. Alternatively, law may be tainted implicitly through other traces within it of the violent past, such as resonant names, terms, structures, or categories, with or without active conceptual continuity. Taint in law may be unattenuated, or could in part be assuaged by doctrinal or other interpretative practices that seek to rectify or temper it. Nevertheless, it is suggested here, the gravity of the past or foundational violence may be such that the taint, be it explicit or implicit, substantive or associative, is indelible: it cannot be ignored.

Secondly, an analysis of tainted law has to be grounded on a particular sort of study. The aim of tainted law as a conceptual structure is to provide a jurisprudential platform for questioning democratically problematic law, based on examination of historical and current socio-political conditions in order to establish the context in which law's (normative and conceptual) substantive, symbolic, narrative and memorial significations operate, and thus why they matter. This requires comparison over time and, as Fraser has indicated, comparison across legal orders so as to identify and assess distinctions and continuities (Fraser, 2005). It also requires a cross-disciplinary approach that draws on law and related theory, as well as politics and history. As such, like the Habermasian approach, it seeks to focus on law and its 
Forthcoming in the International Journal of Law in Context, vol. 7, 2011

legitimacy in a way that integrates and imbricates legal analysis with contextual forces.

Consequently, as it has been shown, the construction and conservation of democracy require an ongoing critical relationship with the anti-democratic past. ${ }^{43}$ This is not to say that a democratic order can only exist in a constant state of anguished reflection, nor that it entails a historicist, deterministic attachment to the values prevailing at a particular foundational moment. ${ }^{44}$ Rather, it does suggest that law in democracy needs to be appraised in terms of values based on a historical line that must not be crossed, a critically constructive appraisal central to ensuring that democracy and the rule of law remain meaningful (Raymond, 1998, p.1196; Bell et al, 2007, p.83).

\section{Conclusion}

Democracy can be understood as having an essential temporal dimension, a relationship with history that entails a remembering, and a positioning, of current democratic practice and evaluation in relation to the (violent) past in

\footnotetext{
${ }^{43}$ For an analysis of a specific manifestation of the critical relationship with the authoritarian past in U.S. law, as part of a study of constitutional interpretation as translation, see Raymond (1998). Raymond examines the use of references to totalitarianism in post-war American legal discourse relating to the affirmation of constitutional limits on governmental authority, police powers and criminal procedure. Raymond shows how totalitarianism is used as a moving target (first in its historical form of Nazism, then during the Cold War period in its Communist sense) indicating an experience to be rejected and against which current norms can be assessed. In her conclusion (pp.1262-1263), Raymond suggests that in American experience, the fading of totalitarianism into the past may diminish its value as a negative comparator and may make it a sort of legal fiction. In contrast, the argument here is that in Italy the ongoing disruptive force of Fascism means that it remains significant as a negative reference point and that, more generally, we must not lose sight of such critical comparison.

${ }^{44}$ Contrast Dworkin, 1998, p.227.
} 
Forthcoming in the International Journal of Law in Context, vol. 7, 2011

response to which it has been developed. In a complex socio-political context in which political memory is still a source of conflict and perceived injustice, law's formal, symbolic and narrative dimensions are imbricated with this past and memories of it, so tensions within and among them where that law can be seen as tainted are negative for democracy. By examining the Italian Penal Code, this article has demonstrated how a contextually sensitive theoretical critique of such tensions can be developed and it has contributed the concept of tainted law, in order to encapsulate the constitutive elements of that critique in a way that is also applicable to similar laws in other systems.

Beyond Italy at the time of writing, the formulation of a bold new form of integrated democracy continues to hold political attention on the European stage and the democracy-driven discourse of human rights continues to be a vital attribute of European political life. Yet numerous European States are still struggling to face their problematic (legal) past, the far right is making alarming electoral gains across the continent, and key Western and Central European countries appear ready to adopt through law the tactics of Europe's darker political history that European integration was intended to overcome. In this context, the importance of addressing the continued existence of echoes of the authoritarian past in tainted law and the significance of historical awareness and memory cannot be overstated. 


\section{Forthcoming in the International Journal of Law in Context, vol. 7, 2011}

\section{References}

- ADORNO, Theodor W. (1977/1986) (trans. Timothy Bahti and Geoffrey Hartman) 'What Does Coming to Terms with the Past Mean?' in Geoffrey H. Hartmann (ed) Bitburg in Moral and Political Perspective. Bloomington: Indiana University Press, 114-129.

- AMNESTY INTERNATIONAL (2001) Italy: G8 Genoa Policing Operation of July 2001 - A Summary of Concerns. AI Index: EUR 30/012/2001 November 2001.

- ARENDT, Hannah (1951/ 1985) The Origins of Totalitarianism. New York: Harcourt.

- BALINT, Jennifer (2001) 'Law's Constitutive Possibilities: Reconstruction and Reconciliation in the Wake of Genocide and State Crime', in Christodoulidis and Veitch, 129-152.

- BARAHONA DE BRITO, Alexandra, GONZALEZ-ENRIQUEZ, Carmen and AGUILAR, Paloma (eds) (2001) The Politics of Memory: Transitional Justice in Democratizing Societies. Oxford: Oxford University Press;

(2001) 'Introduction' in Barahona de Brito et al, 1-39.

- BATTAGLINI, Giulio (1933-34) 'The Fascist Reform of the Penal Law in Italy', American Institute of Criminal Law and Criminology 24: 278-289.

- BATTINI, Michele (translated by Noor Giovanni Mazhar and edited by Stanislao G. Pugliese) (2007) The Missing Italian Nuremberg: Cultural Amnesia and Postwar Politics. Basingstoke: Palgrave Macmillan.

- BELL, Christine, CAMPBELL, Colm and NÍ AOLÁIN, Fionnula (2007) 'Transitional Justice: (Re)conceptualising the Field', International Journal of Law in Context 3: 2: 81-88.

- BENJAMIN, Walter (trans. Jephcott, E.) (1921/1996) 'Critique of Violence' in M. Bullock and M. Jennings (eds) Walter Benjamin: Selected Writings, Volume 1 1913-1926. Cambridge, Mass.: Belknap Press.

- BETTIOL, G. and MANTOVANI, L. (1986) Diritto Penale: Parte Generale. Padua: CEDAM, 4853.

- BIRCH, Anthony H. (2007) The Concepts and Theories of Modern Democracy. London: Routledge.

- BOLLE, Pierre-Henri (1999) 'Reforming Criminal Law', European Journal of Crime, Criminal Law and Criminal Justice 7: 387-396.

- BOSWORTH, R. J. B. and DOGLIANI, Patrizia (1999) 'Introduction' in R. J. B. Bosworth and Patrizia Dogliani (eds) Italian Fascism: History, Memory and Representation. London: Macmillan, $1-9$.

- BOSWORTH, R. J. B. (2006) Mussolini's Italy: Life Under the Dictatorship. London: Penguin Books. 


\section{Forthcoming in the International Journal of Law in Context, vol. 7, 2011}

- BULL, Martin J. and NEWELL, James L. (2005) Italian Politics: Adjustment Under Duress. Cambridge: Polity Press.

- CANALI, Mauro (2009) 'Crime and Repression' in R. J. B. Bosworth (ed.) The Oxford Handbook of Fascism. Oxford: Oxford University Press, 221-238.

- CARLSSON, Bo (2002) 'Jürgen Habermas and the Sociology of Law', in Reza Banakar and MaxTravers An Introduction to Law and Social Theory. Oxford: Hart, 77-96.

- CATTANEO, Mario A. (1981) 'Il Codice Rocco e l'Eredità Illuministico-Liberale', La Questione Criminale 7: 1: 99-110.

- CERTOMA, G. Leroy (1985) The Italian Legal System. London: Butterworths.

- CHRISTODOULIDIS, Emilios and VEITCH, Scott (eds) (2001) Lethe's Law: Justice, Law and Ethics in Reconciliation. Oxford: Hart.

- COSER, Lewis A. (ed. and trans.) (1992) Maurice Halbwachs: On Collective Memory. Chicago: University of Chicago Press.

- COVER, Robert M. (1983) 'Foreword: Nomos and Narrative', Harvard Law Review 97: 4-68; (1986) 'Violence and the Word', The Yale Law Journal 95: 1601-1629.

- CRESPI, Alberto, FORTI, Gabrio and ZUCCALÀ, Giuseppe (2008) Commentario Breve al Codice Penale. Padua: Cedam.

- CZARNOTA, Adam (2001) 'Law as Mnemosyne and as Lethe: Quasi-Judicial Institutions and Collective Memories', in Christodoulidis and Veitch, 115-128.

- DAVIES, Nick (2008) 'The Bloody Battle of Genoa', guardian.co.uk 17th July (02.12.10).

- DE FIGUEIREDO DIAS, Jorge (1995) 'Il Codice Penale Portoghese del 1982 e la Sua Riforma', Rivista Italiana di Diritto e Procedura Penale 38: 1: 25-50.

- DEL GIUDICE, Federico (2007) Codice Penale Spiegato Articolo per Articolo, 12 ${ }^{\text {th }}$ ed. Naples: Gruppo Editoriale Esselibri - Simone.

- DELITALA, Giacomo (1960) 'Codice di procedura penale', in Enciclopedia del Diritto. Milan: Giuffrè Editore, 284-287.

- DELOGU, Tullio (1945) 'L'elemento politico nel codice penale', Archivio Penale 1: 161-195.

- DERRIDA, Jacques (1990) 'Force of Law: The 'Mystical Foundation of Authority'”, Cardozo Law Review 11: 919-1045.

- DOLCINI, Emilio and MARINUCCI, Giorgio (1996) ‘La Constitution et le Droit Pénal en Italie', Revue de Science Criminelle 2: 317-331.

- DONDI, Mirco (1999) ‘The Fascist Mentality after Fascism', in R. J. B. Bosworth and Patrizia Dogliani (eds) Italian Fascism: History, Memory and Representation. London: Macmillan, 144160. 


\section{Forthcoming in the International Journal of Law in Context, vol. 7, 2011}

- DUGGAN, Christopher (1995) 'Italy in the Cold War Years and the Legacy of Fascism', in Christopher Duggan and Christopher Wagstaff (eds) Italy in the Cold War: Politics, Culture and Society 1948-58. Oxford: Berg, 1-24.

- DWORKIN, Ronald (1986/ 1998) Law's Empire. Oxford: Hart.

- DYZENHAUS, David (1996) 'The Legitimacy of Legality', University of Toronto Law Journal 46: 129-180;

(1997) Legality and Legitimacy: Carl Schmitt, Hans Kelsen and Hermann Heller in Weimar. Oxford: Clarendon Press;

(1999) Recrafting the Rule of Law: The Limits of Legal Order. Oxford: Hart.

- EWING, Keith and GEARTY, Connor (2000) The Struggle for Civil Liberties: Political Freedom and the Rule of Law in Britain, 1914-1945. Oxford: Oxford University Press.

- FERRARI, Vincenzo (1981) ‘The Policy of Law and Order in Italy: the Voice of Power and its Impact', International Journal of Law and Sociology 9: 23-39.

- FIANDACA, Giovanni and MUSCO, Enzo (1994) 'Perdita di Legittimazione del Diritto Penale?', Rivista Italiana di Diritto e Procedura Penale 37: 1: 23-63.

- FOOT, John (2009) Italy's Divided Memory. Basingstoke: Palgrave Macmillan.

- FORTI, Simona (2008) 'Spectres of Totality' in Palonen et al, 219-231.

- FRASER, David (2005) Law After Aushwitz: Towards a Jurisprudence of the Holocaust. Durham, North Carolina: Carolina Academic Press.

- FULLER, Lon L. (1958) 'Positivism and Fidelity to Law - A Reply to Professor Hart', Harvard Law Review 71: 4: 630-672.

- FUSANI, Claudia (2002) 'Dal carcere parla Caruso "Vittime di leggi fasciste"', La Repubblica.it 21 ${ }^{\text {st }}$ November (28.08.10).

- GEERTZ, Clifford (1973/1993) The Interpretation of Cultures. London: Fontana Press.

- GENOA SOCIAL FORUM, (2002) Genova: Il Libro Bianco. Milan: Nuova Iniziativa Editoriale SPA.

- GENTILE, Emilio (2002) 'Fascism in Power: the Totalitarian Experiment', in Lyttleton, 139174.

- GINSBORG, Paul (1990) A History of Contemporary Italy 1943-1980. London: Penguin Books.

- GORDON, Robert W. (1984) ‘Critical Legal Histories’, Stanford Law Review 36: 57-125.

- GRANDE, Elisabetta (2002) 'Criminal Justice: The Resistance of a Mentality', in Jeffrey S. Lena and Ugo Mattei (eds) Introduction to Italian Law. The Hague: Kluwer, 181-216.

- HABERMAS, Jürgen (1988) 'Concerning the Public Use of History', New German Critique 44: 40-50; 


\section{Forthcoming in the International Journal of Law in Context, vol. 7, 2011}

(1996) (trans. W Rehg) Between Facts and Norms. Cambridge: Polity Press.

- HART, H. L. A. (1958) 'Positivism and the Separation of Law and Morals', Harvard Law Review 71: 4: 593-629.

- HERRMANN, Irène (2008) 'Democratization and the Instrumentalization of the Past', in Palonen et al, 167-183.

- HOOPER, John (2008) 'Police and Doctors Convicted of Genoa G8 Brutality Avoid Jail', guardian.co.uk 15 July (02.12.10).

- JOERGES, Christian and SINGH GHALEIGH, Navraj (2003) Darker Legacies of Law in Europe: the Shadow of National Socialism and Fascism over Europe and its Legal Traditions. Oxford: Hart.

- JONES, Tobias (2008) 'The Triumph of the Right?', The Guardian G2 2nd May: 4-7;

(2003) The Dark Heart of Italy. London: Faber \& Faber.

- KALYVAS, Andreas (2008) Democracy and the Politics of the Extraordinary: Max Weber, Carl Schmitt, and Hannah Arendt. Cambridge: Cambridge University Press.

- KELMAN, Mark (1987) A Guide to Critical Legal Studies. London: Harvard University Press.

- KLINKHAMMER, Lutz (2010) ‘Was There a Fascist Revolution? The Function of Penal Law in Fascist Italy and Nazi Germany', Journal of Modern Italian Studies 15: 3: 390-409.

- KNOX, MacGregor (2002) ‘Fascism: Ideology, Foreign Policy and War' in Lyttleton, 105-138.

- LUSTGARTEN, Laurence (2003) "'A Distorted Image of Ourselves": Nazism, “Liberal” Societies and the Qualities of Difference' in Joerges and Singh Ghaleigh, 113-132.

- LYTTLETON, Adrian (2002) Liberal and Fascist Italy. Oxford: Oxford University Press.

- MACCANICO, Yasha (2008) 'Italy: Making Sense of the Genoa G8 Trials and Aftermath', Statewatch 18: 4: 2-7.

- MACCORMICK, Neil (2007) Institutions of Law. Oxford: Oxford University Press.

- MANTOVANI, Ferrando (2007) Diritto Penale: Parte Generale. Padua: Cedam.

- MANZINI, Vincenzo, updated by P. Nuvolone and G. D. Pisapia (1981) Trattato di Diritto Penale Italiano. Turin: Utet.

- MARCONI, Pio (1981) ‘Codice Penale e Regime Autoritario', La Questione Criminale 7: 1: 129137.

- MERRYMAN, John Henry (1969/1985) The Civil Law Tradition, 2nd ed. Stanford, Ca.: Stanford University Press.

- MINOW, Martha(1998) Between Vengeance and Forgiveness. Boston: Beacon Press.

- MONTANELLI, Indro and CERVI, Mario (1985/2007) L'Italia della Repubblica: 2 Giugno 1946 18 Aprile 1948. Milan: Biblioteca Universale Rizzoli. 


\section{Forthcoming in the International Journal of Law in Context, vol. 7, 2011}

- MÜLLER, Jan-Werner (2001) ‘East Germany: Incorporation, Tainted Truth, and the Double Vision', in Barahona de Brito et al, 248-274.

- MUSIO, Sarah (2005) La vicenda del Codice Rocco nell'Italia repubblicana. Florence: http://www.altrodiritto.unifi.it/ricerche/law-ways/musio/index.htm (24.08.10).

- NEPPI MODONA, Guido (2007) 'Principio di Legalità e Giustizia Penale nel Periodo Fascista', Quaderni Fiorentini per la Storia del Pensiero Giuridico Moderno 36: 983-1005.

- NUVOLONE, Pietro (1981) 'La Parte Generale del Codice Rocco dopo Cinquant'anni', La Questione Criminale 7: 1: 39-48.

- PALAZZO, Francesco and PAPA, Michele (2000) Lezioni di Diritto Penale Comparato. Turin: G. Giappichelli Editore.

- PALONEN, Kari, PULKKINEN, Tuija and ROSALES, José María (2008) The Ashgate Research Companion to the Politics of Democratization in Europe: Concepts and Histories. Aldershot: Ashgate.

- PAVONE, Claudio (1974) ‘La Continuità dello Stato: Istituzioni e Uomini’ in Enzo Piscitelli et al Italia 1945-48: Le Origini della Repubblica. Turin: G. Giappichelli Editore.

- PAXTON, Robert O. (2004) The Anatomy of Fascism. London: Penguin Books.

- PIASENZA, Paolo (1979) ‘Tecnicismo Giuridico e Continuità dello Stato: Il Dibattito sulla Riforma del Codice Penale e della Legge di Pubblica Sicurezza', Politica del Diritto 261-317.

- PIVATO, Stefano (2007) Vuoti di Memoria: Usi e Abbusi della Storia nella Vita Pubblica Italiana. Bari: Editori Laterza.

- PLOSCOWE, Morris (1945) 'Purging Italian Criminal Justice of Fascism', Columbia Law Review 45: 2: 240-264.

- PŘIBÁŇ, Jiř́ (2007) Legal Symbolism: On Law, Time and European Identity. Aldershot: Ashgate; (2009) 'Symbolism of the Spirit of the Laws: a Genealogical Excursus to Legal and Political Semiotics', International Journal of the Semiotics of Law 22: 179-195.

- PULITANÒ, Domenico (2007) Diritto Penale, 2nd ed. Turin: G. Giappichelli Editore.

- RAYMOND, Margaret (1998) 'Rejecting Totalitarianism: Translating the Guarantees of Constitutional Criminal Procedure', North Carolina Law Review 76: 1193-1263.

- RIERA, Jaime M. Peris (1996) 'Il Lungo Camino Verso un Nuovo Codice Penale della Democrazia in Spagna', Rivista Italiana di Diritto e Procedura Penale 39:1: 3-20.

- ROMANO, Mario (1987) Commentario Sistematico del Codice Penale. Milan: Giuffrè Editore.

- SARAT, Austin and KEARNS, Thomas R. (1995) 'Introduction' in Austin Sarat and Thomas

R. Kearns Law's Violence. Ann Arbor: University of Michigan Press, 1-21. 


\section{Forthcoming in the International Journal of Law in Context, vol. 7, 2011}

- SHABI, Rachel and HOOPER, John (2005) 'Now, the Reckoning', The Guardian Weekend 22 ${ }^{\text {nd }}$ January: 22-29.

- SINISCALCO, Marco (1976) 'I Principi del Sistema Penale e la Costituzione', Rivista Italiana di Diritto e Procedura Penale 19: 1121-1132.

- SKINNER, Stephen (2003) 'Death in Genoa: the G8 Summit Shooting and the Right to Life', European Journal of Crime, Criminal Law and Criminal Justice 11: 233-252;

(2009) 'Stories of Pain and the Pursuit of Justice: Law, Violence, Experience and Jurisprudence', Law, Culture and the Humanities 5: 131-155.

(2010) 'Case Analysis - Giuliani and Gaggio v. Italy: the Context of Violence, the Right to Life and Democratic Values', European Human Rights Law Review 1: 85-93.

- STATEWATCH (2001) 'Genoa: An Italian View of "Public Order Policing" Italian Style' Statewatch 11:3/4: 1-3.

- STEINER, H. Arthur (1936) 'The Fascist Conception of Law', Columbia Law Review 36: 8: 1267-1283.

- STOLLEIS, Michael (trans. Dunlap, Thomas) (1998) Law Under the Swastika: Studies on Legal History in Nazi Germany. London: The University of Chicago Press.

- STOLTZFUS, Nathan and BOSWORTH, R. J. B. (2009) 'Memory and Representations of Fascism in Germany and Italy', in Bosworth, R. J. B. The Oxford Handbook of Fascism. Oxford: Oxford University Press, 566-585.

- TEITEL, Ruti G. (2000) Transitional Justice. Oxford: Oxford University Press.

- TORPEY, J. (2003) 'Introduction: Politics and the Past' in J Torpey (ed) Politics and the Past. Lanham: Rowman and Littlefield Publishers, 1-34.

- VASSALLI, Giuliano (1960) ‘Codice Penale' in Enciclopedia del Diritto. Milan: Giuffrè Editore, 261-279;

(1974) ‘The Reform of the Italian Penal Code', Wayne Law Review 20: 4: 1031-1069.

- WALDRON, Jeremy (2004) 'Legal and Political Philosophy' in Jules Coleman and Scott Shapiro (eds) The Oxford Handbook of Jurisprudence and Political Philosophy. Oxford: Oxford University Press, 352-381.

- WATKIN, Thomas G. (1997) The Italian Legal Tradition. Dartmouth: Ashgate.

- WISE, Edward M. (1978) 'Introduction' in Edward M. Wise with Allen Maitlin (1978) The Italian Penal Code. London: Sweet \& Maxwell Limited, xxi-xlvi. 